Anna Tyl

Uniwersytet Łódzki

\title{
Prestiż zawodu nauczyciela
}

\section{Wprowadzenie}

Najbardziej pożądanymi przez przedstawicieli każdego społeczeństwa dobrami są: bogactwo, władza i prestiż. Cenione społecznie dobra to takie, których ludzie powszechnie pragną, ale ich zasób jest znacznie ograniczony, zatem mogą być one dostępne tylko dla nielicznych jednostek ${ }^{1}$.

Trzecie $\mathrm{z}$ wymienionych dóbr - prestiż, będące przedmiotem rozważań zamieszczonych w poniższym tekście, zostało określone w słowniku W. Kopalińskiego jako: „autorytet, wpływ, znaczenie, mir, poważanie (u ludzi)”2. W literaturze przedmiotu można znaleźć wiele określeń, za pomocą których wyjaśnia się znaczenie słowa „prestiż”. Są to m.in. takie określenia, jak: ranga, pozycja, doniosłość, ważność, znaczenie, istotność, waga, wpływ, autorytet, estyma, mir, powaga, poważanie, ważność, poszanowanie, szacunek, uznanie, respekt, posłuch, popularność, cześć, chwała, renoma, reputacja, splendor, uznanie społeczne, akceptacja, aplauz i sława.

W naukach społecznych równolegle funkcjonują dwa terminy: „prestiž” i „prestiż społeczny”. Określenia „prestiž” używa się najczęściej, gdy mowa o prestiżu osobistym, którego źródłem są osobowościowe właściwości człowieka, w przeciwieństwie do prestiżu społecznego, który ma związek z miejscem jednostki w strukturze społecznej. Często zdarza się jednak, że (podobnie jak w przypadku tego opracowania) w wypowiedzi pojawia się słowo "prestiż", które traktuje się jako skrót i stosuje zamiast określenia "prestiż społeczny”.

$\mathrm{Na}$ ocenę prestiżu społecznego wpływają najczęściej takie czynniki, jak: wykonywany zawód, wykształcenie, stan cywilny i rodzina, miejsce za-

\footnotetext{
${ }^{1}$ P. Sztompka, Socjologia. Analiza społeczeństwa, Kraków 2010.

${ }^{2}$ W. Kopaliński, Słownik wyrazów obcych i zwrotów obcojęzycznych z almanachem, Warszawa 2000, s. 405.

${ }^{3}$ A. Janowski, R. Stachyra, Prestiz ucznia wśród rówieśników, Warszawa 1985, s. 7-12.
} 
mieszkania, uzyskiwane dochody i posiadany majątek, jak również działalność społeczna, odniesione sukcesy życiowe i zawodowe, autorytet, posiadana władza, wpływy itp. ${ }^{4}$

Mimo że prestiż związany z walorami osobistymi nauczyciela wydaje się niezwykle istotny w badaniach zjawisk pedagogicznych, to w tekście zakres rozumienia tego pojęcia zostanie zawężony do rozważań nad prestiżem pozycyjnym, który „wynika z atrybutów zajmowanych pozycji - zawodu, stanowiska”, czyli do prestiżu pozycji zawodowej nauczyciela.

\section{Istota pojęcia „prestiż zawodów”}

W terminologii naukowej „prestiż” zalicza się do pojęć teoretycznych, a „nazwy prestiż używa się do wyodrębnienia w znaczącą całość rozproszonych przejawów mieszaniny szacunku, respektu i godności”'6. Istotą prestiżu jest to, że powinno to być dobro rzadko występujące, bowiem ma on wartość tylko wtedy, gdy dotyczy nielicznej grupy. Jak wyjaśnia P. Sztompka, „gdyby wszyscy byli sławni, to nie byłby sławny nikt”7. Autor twierdzi, że ludzie zabiegają o prestiż z dwóch powodów. Pierwszy można wyjaśnić, posługując się koncepcją jaźni odzwierciedlonej, zgodnie z którą wpływ na samoocenę jednostek ma to, na ile cenią ich inni ludzie. Człowiek przyglądający się własnemu odbiciu lustrzanemu, w którym zauważa uznanie społeczne towarzyszące jego osobie, ma tendencje do podwyższania samooceny. Satysfakcja wywołana zachowaniem innych ludzi, związanym z okazywaniem danej osobie oznak prestiżu, jest dla niej wartością autoteliczną. Posiadanie prestiżu ma również walor instrumentalny, ponieważ może być pomocny w zdobywaniu innych dóbr, także takich, jak bogactwo i władza. Znany i ceniony aktor (w przeciwieństwie do całej masy przeciętnych i nieznanych przedstawicieli tego zawodu) może zawierać intratne kontrakty reklamowe, czy też negocjować wysokość otrzymywanej gaży. Politycy zabiegają o akceptację i zaufanie społeczne, ponieważ dzięki prestiżowi społecznemu mogą zachować lub zdobyć władzę

Najbardziej czytelnym wskaźnikiem prestiżu w skali globalnej jest prestiż wykonywanego przez ludzi zawodu, traktowany jako wypadkowa opi-

\footnotetext{
${ }^{4}$ [Hasło:] Prestiż społeczny, [w:] P. Dobrodziej, Słownik badań marketingowych, rynkowych $i$ społecznych, http://dobre badania.pl/słownik-badawczy.html (dostęp: 2.05.2013).

${ }^{5} \mathrm{H}$. Domański, Co wynika z badań dla prestiżu nauczyciela w Polsce?, referat wygłoszony w czasie Kongresu Polskiej Edukacji w Warszawie w dniu 16.06.2013 r.

${ }^{6}$ Idem, Prestiz, Wrocław 1999, s. 10.

${ }^{7}$ P. Sztompka, Socjologia..., s. 334.

${ }^{8}$ Ibidem.
} 
nii respondentów danego kraju, uwzględniająca ocenę cech przynależnych grupie zawodowej, których jednostkowo nie musi posiadać każdy z reprezentantów danego zawodu?

„Prestiż zawodów” to „ocena i sposób postrzegania przez ludzi wybranych profesji, a w szczególności ich użyteczności i zaufania, jakim cieszą się w społeczeństwie"10. Obecnie w stratyfikacji zawodowej prestiż jest zazwyczaj osiągnięty, a nie przypisany, np. ze względu na pochodzenie. Zdaniem Jacka Wasilewskiego, ocena prestiżu zawodowego może uwzględniać wiele elementów, takich jak: „wymagany poziom kwalifikacji i wykształcenia, zajmowane stanowisko, ponoszona odpowiedzialność, zakres podejmowanych decyzji, uciążliwość pracy, społeczne znaczenie zawodu, stałość i pewność pracy oraz możliwość uzyskania dodatkowego wykształcenia"11. Gabriela Jabłońska uważa, że największe znaczenie dla oceny prestiżu danego zawodu ma liczebność kadr. Zbyt niska podaż pracowników, od których wymaga się posiadania szczególnych umiejętności lub długoletniego przygotowania zawodowego, wpływa na wzrost popytu na przedstawicieli tej grupy zawodowej i gwarantuje jej wyższy prestiż (i uposażenie). Wyższy prestiż zawodowy posiadają także pracownicy, których trudno jest zastąpić lub pełnią społecznie istotne funkcje. Zdaniem Autorki, wraz ze wzrostem liczby studentów (a dokładniej: absolwentów szkół wyższych) obniżyła się wartość wyższego wykształcenia jako czynnika istotnego dla rangi zawodów inteligenckich ${ }^{12}$.

Badania prestiżu zawodów polegają na zebraniu opinii respondentów, których zadaniem jest przypisanie oceny do zawodów wymienionych na zamkniętej liście, $\mathrm{z}$ uwzględnieniem osobistego uznania i szacunku dla każdego z nich. Badacze przeprowadzają agregację odpowiedzi poprzez obliczenie średniej lub odsetka osób, które wskazały dany zawód jako cieszący się „doskonałą pozycją społeczną”. Podsumowanie wyników pozwala na stworzenie rankingu, który tworzy tzw. „skalę zawodów”13.

\footnotetext{
${ }^{9}$ Informację podano za: H. Domański, Prestiż.

${ }^{10}$ [Hasło:] Prestiż zawodów...

${ }^{11}$ J. Wasilewski, [za:] G. Jabłońska, W pogoni za prestiżem, czyli najbardziej poważane zawody w Polsce, http://www.rynekpracy.pl/artykul.php/wpis.107 (dostęp: 7.04.2009).

${ }^{12} \mathrm{G}$. Jabłońska, W pogoni za prestiżem...

${ }^{13}$ [Hasło:] Prestiz zawodów, [w:] G. Marshall (red.), Słownik socjologii i nauk społecznych, Warszawa 2006.
} 


\section{Hierarchia prestiżu zawodów}

Miejsce w hierarchii prestiżu różnych zawodów jest wynikiem percepcji danej grupy zawodowej w określonym czasie i w różnych okolicznościach oraz wartościowania tych spostrzeżeń przez osoby dokonujące oceny. „Gradacja prestiżu jest jak zwierciadło rzeczywistości, przefiltrowane przez umysł percepcji jednostek oferujących prestiż" ${ }^{14}$.

Rejestr zawodów poddawanych hierarchizacji jest ograniczony do kilkunastu lub kilkudziesięciu zawodów, powinien jednak odzwierciedlać strukturę i przekrój badanego społeczeństwa oraz klasyfikację zawodów obowiązującą w danym okresie, ponieważ „zmiany społeczne i ekonomiczne stale modyfikują strukturę zawodów i ograniczają możliwość odzwierciedlenia danej struktury przez konkretną klasyfikację zawodów w dłuższym okresie"15.

Usytuowanie danej grupy zawodowej na skali zawodów we wszystkich społeczeństwach jest zbliżone. Na szczycie tej hierarchii znajdują się profesjonaliści, nieco niżej - pracownicy wykwalifikowani, a listę zamykają pracownicy niewykwalifikowani. Gradacja prestiżu niemal całkowicie pokrywa się ze strukturą klasową społeczeństwa, choć przeglądając wyniki przeprowadzonych w ostatnich latach sondaży można dostrzec nieznaczne odstępstwa od tego modelu, np. wśród zawodów cieszących się najmniejszym szacunkiem (mimo że nie są one stereotypowo kojarzone z klasą niższą) znalazły się takie zawody, jak: radny gminy, makler giełdowy czy działacz partii politycznej. Odwrotną tendencję można zaobserwować, przyglądając się rankingowi zawodu górnika - pracy fizycznej, obdarzanej jednak bardzo dużym prestiżem społecznym ${ }^{16}$.

W Polsce badania prestiżu zawodów od wielu lat prowadzi m.in. CBOS. Ostatni z powszechnie dostępnych raportów ${ }^{17}$ charakteryzuje badania przeprowadzone w listopadzie 2008 roku na liczącej ponad tysiąc osób reprezentatywnej próbie losowej dorosłych mieszkańców Polski. Zadaniem ankietowanych było ocenienie wymienionych w kwestionariuszu zawodów w pięciopunktowej skali szacunkowej, wskazującej poziom poważania dla danego zawodu jako: bardzo duży, duży, średni, mały, bardzo mały. W tym sondażu zawód nauczyciela uplasował się na siódmej pozycji za: profeso-

\footnotetext{
${ }^{14}$ H. Domański, Prestiż, s. 14.

${ }^{15}$ [Hasło:] Klasyfikacja zawodów, [w:] G. Marshall (red.), Słownik socjologii..., s. 148.

${ }^{16}$ Praca (II) - Czynnik stratyfikacji społecznej, http://socjoszpieg.blox.pl/2007/01/Praca-II-Czynnik-stratyfikacji-spolecznej.html (dostęp: 12.01.2007).

${ }^{17}$ M. Feliksiak, Prestiżzawodów, Komunikat CBOS nr 4073, Warszawa 2009 (dostęp: 20.01.2009).
} 
rem uniwersytetu, strażakiem, górnikiem, pielęgniarką, lekarzem i inżynierem pracującym w fabryce. W komentarzu czytamy: ,jeżeli chodzi o zawód nauczyciela, warto zauważyć, że relatywnie częściej dużym poważaniem darzą go starsi badani niż młodsi czy też osoby uczące się, studiujące"18. W stosunku do poprzednich badań CBOS należy odnotować nieznaczny, choć zauważalny, spadek pozycji zawodowej nauczyciela. I tak: w raporcie z 1999 roku $^{19}$ zawód nauczyciela znalazł się na trzeciej pozycji po: profesorze uniwersytetu i lekarzu; w 1996 roku $^{20}$ - na miejscu czwartym (po: profesorze uniwersytetu, lekarzu i górniku), w 1995 roku $^{21}$ - na trzecim miejscu (po profesorze uniwersytetu i lekarzu), a w $1993^{22}$ i 1988 roku $^{23}$ - na drugim miejscu (po lekarzu).

W badaniu OBOP, przeprowadzonym w lutym 2000 roku na liczącej ponad tysiąc osób reprezentatywnej grupie Polaków powyżej 15 roku życia, zawód nauczyciela określono jako jeden z najbardziej stresujących zawodów (na drugim miejscu - po lekarzu), w którym relatywnie trudno znaleźć pracę (na miejscu drugim - po urzędniku). W rankingu zawodów najbardziej interesujących (ciekawych) zawód nauczyciela znalazł się na dziesiątej pozycji, a wśród zawodów nudnych (nieciekawych, monotonnych) - na pozycji jedenastej. W hierarchii zawodów najbardziej odpowiedzialnych Polacy zakwalifikowali nauczyciela na miejscu czwartym, tuż za: lekarzem, pilotem i kierowcą. Uznano go także za zawód szczególnie trudny (na miejscu piątym, za: lekarzem, górnikiem, pilotem i hutnikiem). Warto podkreślić, że choć wśród zawodów dających największy prestiż nauczyciel znalazł się na drugim miejscu, to respondenci wskazywali go kilkakrotnie rzadziej niż zawód lekarza, który zakreśliło najwięcej badanych ${ }^{24}$.

Wśród różnych rankingów, licznie pojawiających się w Internecie, zawodu nauczyciela nie wskazano na liście zawodów najłatwiejszych ${ }^{25}$ ani naj-

\footnotetext{
${ }^{18}$ Ibidem, s. 3.

${ }^{19}$ M. Falkowska, Prestiż zawodów, Komunikat CBOS nr 2086, Warszawa 1999 (data wydania: 3.03.1999).

${ }^{20}$ B. Rogulska, Prestiż zawodów a struktura zarobków, Komunikat CBOS nr 1635, Warszawa 1996 (data wydania: 1.09.1996).

${ }^{21}$ M. Falkowska, Prestiż zawodów, Komunikat CBOS nr 1355, Warszawa 1995 (data wydania: 9.03.1995).

${ }^{22}$ S. Mocek, Prestiż zawodów, Komunikat CBOS nr 0978, Warszawa 1993 (data wydania: 10.03.1993).

${ }^{23}$ C. Sowiński, Jakie zawody sa przez ludzi cenione, Komunikat CBOS nr 0321, Warszawa 1988 (data wydania: 15.02.1988).

${ }^{24}$ Polacy o zawodach, Komunikat OBOP, Warszawa 2000.

${ }^{25}$ Jaki jest najłatwiejszy zawód świata?, http://pytamy.pl/kat,17,title,jaki-jest-najlatwiejszyzawod-swiata,pytanie.html (dostęp: 19.10.2009).
} 
bardziej hańbiących ${ }^{26}$, ale za to znalazł się na liście najbardziej romantycznych zawodów na świecie. $\mathrm{W}$ uzasadnieniu jeden $\mathrm{z}$ internautów napisał:

To może niektórych zdziwić, ale wydaje mi się to niezmiernie romantyczne. Uczyć następne pokolenia, oddawać im część siebie, swoją wiedzę i pasję. Jakie to musi być uczucie dla nauczyciela, gdy zarazi swoją fascynacją do przedmiotu uczniów, albo chociaż jednego ucznia. A potem, gdy jest już starszy i widzi, jak jego podopieczni wyrośli, żyją w świecie, osiągają sukcesy, zmieniają się, dojrzewają... I on wie, że miał w tym swój udział ${ }^{27}$.

\section{Prestiż zawodu nauczyciela różnych poziomów kształcenia ogólnego}

W tym fragmencie tekstu zostaną przedstawione wyniki wycinka badań, prowadzonych przez autorkę w 2011 i 2012 roku, dotyczących prestiżu zawodu nauczyciela. Pilotażowymi badaniami ankietowymi objęto łącznie grupę 150 osób, w tym - w drugiej części badań pilotażowych, których wyniki zostaną przedstawione poniżej - uczestniczyło 90 osób, po 30 przedstawicieli z każdej z trzech grup zawodowych. Poza nauczycielami, których badanie bezpośrednio dotyczyło, o wypełnienie kwestionariusza ankiety poproszono przedstawicieli dwóch różnie sytuowanych w rankingach środowisk zawodowych - osoby należące do grupy wysoko sytuowanych w rankingu zawodów to przedstawiciele środowiska medycznego i osoby należące do grupy niżej sytuowanej w rankingu zawodów to pracownicy fizyczni. W badaniach uczestniczyło zatem 30 przedstawicieli środowiska nauczycielskiego (10 nauczycieli szkół podstawowych, 10 nauczycieli ze szkół ponadpodstawowych i 10 nauczycieli akademickich - pracowników katedr pedagogicznych), 30 przedstawicieli środowiska medycznego (10 lekarzy, 10 pielęgniarek i 10 farmaceutów) oraz 30 przedstawicieli pracowników fizycznych (10 portierów, 10 pracowników firm sprzątających i 10 niewykwalifikowanych pracowników fizycznych, zatrudnionych w budownictwie).

Z przeprowadzonych badań wynika, że nauczyciele oceniają prestiż swojego zawodu niżej niż przedstawiciele innych zawodów. Zdaniem respondentów, kształtuje się on w Polsce na poziomie średnim. Nauczyciele najczęściej oceniali go jako niski albo przeciętny, a pozostali badani - jako przeciętny, wysoki, a nawet (w grupie pracowników fizycznych) jako bar-

\footnotetext{
${ }^{26}$ Najbardziej hańbiący zawód dla k/m to?, http://pytamy.pl/kat,6,title,najbardziej-hanbiacyzawod-dla-k-m-to,pytanie.html (dostęp: 14.04.2009).

27 Najbardziej romantyczny zawód na świecie?, http://pytamy.pl/kat,12,title,najbardziejromantyczny-zawod-na-swiecie,pytanie.html (dostęp: 19.05.2008).
} 
dzo wysoki. Żaden z respondentów nie przypisał go do kategorii „bardzo niski”. Wyniki badań własnych dotyczące zaniżonej samooceny nauczycieli w stosunku do powszechnej percepcji prestiżu zawodu nauczyciela nie są zaskakujące. Taki wniosek można wysnuć, przebywając w środowisku nauczycieli lub wsłuchując się w doniesienia medialne, o czym świadczą choćby tytuły artykułów: Gdzie ten prestiż?28 (mowa o prestiżu zawodu nauczyciela), Obyś cudze dzieci uczy ${ }^{29}$, Roszczeniowe samoluby ${ }^{30}$ czy prezentowane w telewizji obrazy z nauczycielem $z$ koszem na głowie w roli głównej ${ }^{31}$.

Prestiż pozycji zawodowej nauczyciela nie zmienił się zdaniem większości ankietowanych w ciągu ostatnich dziesięciu lat. Jedynie nauczyciele szkół podstawowych wskazywali, że w tym przedziale czasowym nieznacznie się on pogorszył, a nauczyciele szkół ponadpodstawowych (szczególnie gimnazjów), że się zdecydowanie pogorszył. Prognozy na przyszłość były - zdaniem respondentów - nieco bardziej optymistyczne. Jedynie kilka osób (nie tylko z grupy nauczycieli) było zdania, że w perspektywie najbliższych lat hierarchia prestiżu nauczyciela będzie ulegała dalszej degradacji.

Respondentów poproszono także o uszeregowanie podanych dwunastu zawodów (adwokat, lekarz, pielęgniarka, krawcowa, rolnik, strażak, żołnierz zawodowy, psycholog, dziennikarz, kucharz, górnik, nauczyciel) od zawodów - zdaniem respondentów - cieszących się największym prestiżem, do tych, które mają najmniejszy prestiż. Rankingi sporządzone w trzech grupach badanych nieco się od siebie różniły. Nauczyciele najczęściej przypisywali zawodowi nauczyciela miejsca od 5 do 8 , pracownicy fizyczni od 3 do 5, a przedstawiciele środowiska medycznego - od 4 do 7.

Zdaniem większości badanych, dla oceny wysokości prestiżu ma znaczenie, czy nauczyciel jest zatrudniony w szkole państwowej czy w prywatnej. Osoby te znacznie częściej wskazywały nauczyciela szkoły państwowej jako tego, który cieszy się większym prestiżem.

${ }^{28}$ M. Goetz, Gdzie ten prestiż?, http://www.eurydice.org.pl/sites/eurydice.org.pl/files/gtp.pdf (dostęp: 25.01.2013).

${ }^{29}$ I. Majewska-Opiełka, Obyś cudze dzieci uczył!, „Edukacja i Dialog” 2008, nr 3.

${ }^{30} \mathrm{~W}$ artykule M. Goetz, Roszczeniowe samoluby, opublikowanym w „Przekroju” 24.06.2012, autorka nawiązuje do wywiadu, którego udzielił L. Balcerowicz „Rzeczpospolitej” (11.06.2012). Włączając się do dyskusji na temat Karty nauczyciela, były premier określił nauczycieli jako grupę roszczeniową, która dążąc do własnych korzyści, działa na niekorzyść uczniów i gospodarki rynkowej, co prowadzi Polskę do problemów finansowych, z jakimi obecnie boryka się Grecja.

${ }^{31}$ Wydarzenie miało miejsce 19 maja 2003 r. Filmik, który nakręcili uczniowie, emitowany był wówczas w telewizji, ale do tej pory można go znaleźć na YouTube pt. Kosz na głowie nauczyciela lub obejrzeć inne obrazy, np.: Zwyczajna lekcja plastyki w klasie IIIb; Lekcja języka polskiego w klasie Ib; Tak się bawimy na lekcji religii, czy też: Znęcają się nad nauczycielem - cz. 2. 
Kolejne pytanie dotyczyło zróżnicowania prestiżu nauczycieli uczących różnych przedmiotów. Wszyscy ankietowani byli zdania, że jest to ważny czynnik różnicujący. Najwyższe pozycje w hierarchii przypisywano nauczycielom matematyki, fizyki, języków obcych i polonistom, a najniższe nauczycielom w-f, podstaw przedsiębiorczości, przedszkola i katechetom, tuż za nauczycielami klas początkowych, muzyki i plastyki.

Zdaniem respondentów, ważne jest także to, na jakim poziomie kształcenia znajdują się uczniowie, z którymi pracuje nauczyciel. Zdecydowana większość ankietowanych przypisała osobie uczącej zagadnień z tego samego przedmiotu na studiach wyższych wyższy prestiż niż nauczycielom liceum, następnie gimnazjum i szkoły podstawowej.

Badani nie byli zgodni co do tego, czy wyższy prestiż przyznać osobom uczącym w szkołach masowych czy specjalnych. Połowa ankietowanych była zdania, że miejsce zatrudnienia (typ szkoły) dla hierarchii prestiżu nie ma znaczenia, podobnie jak to, czy nauczyciel pracuje w środowisku miejskim czy wiejskim. Większość osób, które uważały przeciwnie, wskazały nauczycieli szkół wiejskich jako tych, którym przypisuje się wyższy prestiż, ale tylko w środowisku lokalnym.

\section{Czynniki wpływające na prestiż zawodu nauczyciela}

W czasie prowadzonych przez autorkę badań poproszono respondentów o określenie, w jakim stopniu na wysokość prestiżu grupy zawodowej nauczycieli wpływają czynniki wymienione w kwestionariuszu ankiety.

Zdaniem większości badanych, medialny wizerunek wpływa negatywnie na pozycję nauczycieli w rankingu zawodów. Zdecydowanie negatywny wpływ stwierdziło blisko $3 / 4$ ankietowanych, w tym - wszyscy nauczyciele.

Drugi z wymienionych czynników - poziom zarobków nauczycieli - także negatywnie, zdaniem respondentów, wpływa na postrzeganie tej grupy zawodowej. Przy czym - co zauważył jeden z ankietowanych: „ważne tu jest, czy ktoś myśli, że nauczyciele zarabiają zbyt mało, czy zbyt dużo". Autor tej wypowiedzi wyjaśnił, że jego zdaniem „zdecydowanie negatywnie na wizerunek nauczyciela wpływa to, że zarabiają dużo przy tak małym nakładzie pracy i to się ludziom nie podoba, dlatego mają niższy prestiż". Inni respondenci byli raczej zdania, że im wyższe uposażenie pracownika (nauczyciela), na tym wyższy zasłużył on prestiż. 
Warunki pracy nauczycieli raczej nie mają wpływu na postrzeganie profesji nauczyciela. Część nauczycieli była jednak zdania, że właśnie kiepskie warunki pracy wpływają na obniżenie ich prestiżu.

Wpływ wykształcenia na prestiż nauczyciela jest znaczny i - zdaniem respondentów - determinuje pozytywne postrzeganie tej grupy zawodowej. Sposób jednak selekcji kandydatów na studia pedagogiczne (nauczycielskie) jest czynnikiem, który zdaniem większości nauczycieli i ponad połowy badanych z pozostałych grup, powoduje utratę prestiżu zawodu nauczyciela.

Przedstawiciele wszystkich grup respondentów twierdzą, że protesty nauczycieli, dopominanie się tej grupy zawodowej o swoje prawa, negatywnie wpływają na odbiór środowiska nauczycieli w społeczeństwie.

Roszczeniowa postawa rodziców wobec placówek oświatowych i brak szacunku uczniów do nauczycieli to, zdaniem respondentów, najważniejsze determinanty obniżenia prestiżu zawodu nauczyciela (szczególnie w ostatnich latach), natomiast widoczna satysfakcja z wykonywanej pracy (dostrzegana - co podkreślali ankietowani - tylko u niektórych nauczycieli) pośrednio wpływa na wzrost prestiżu nauczyciela.

\section{Zakończenie}

$\mathrm{Na}$ stronie podlaskiej Strefy Biznesu opublikowano rozmowę Agaty Szewczenko ${ }^{32}$ z Jackiem Santorskim, którego zdaniem słowo "prestiż” przybiera różne znaczenia w zależności od tego, jakie wartości są uznawane przed dane środowisko, bo - jak wskazano w tytule cytowanego tekstu - dla jednych prestiż to długo działająca firma, a dla innych rolex. Z badań CBOS wynika jednak, że opinie na temat profesji nauczyciela są zbliżone we wszystkich badanych grupach, bez względu na to, czy osoby oceniające mają bezpośredni kontakt z osobami zatrudnionymi w zawodzie. Wśród respondentów dominuje przekonanie, iż „nauczyciele mają wysokie kwalifikacje i są gotowi je zwiększać, wykonują pracę dającą im dużo satysfakcji, mają poczucie misji, a także cieszą się szacunkiem społecznym"33. Sami nauczyciele częściej niż przedstawiciele innych zawodów kwestionują opinię o relatywnie wysokim prestiżu przypisanym środowisku nauczycieli. Zdaniem H. Domańskiego, zaniżona samoocena nauczycieli „rzutuje na

\footnotetext{
${ }^{32}$ A. Szewczenko, Jacek Santorski: Dla jednych prestiż to długo działająca firma. Dla drugich - Rolex, http://www.podlaskie.strefabiznesu.pl/artykul/jacek-santorski-dla-jednych-prestiz-dlugodzialajaca-firma-dla-drugich-rolex-32815.html (dostęp: 25.03.2010).

${ }^{33}$ M. Feliksiak, Wizerunek nauczycieli, Komunikat CBOS nr 4753, Warszawa 2012 (data publikacji: 19.12.2012), s. 5 .
} 
realizację funkcji zawodowych, czyli na jakość edukacji w Polsce"34. W tym kontekście niezwykle istotne wydaje się pytanie o możliwości podniesienia samooceny polskich nauczycieli. Realne odczuwane przez przedstawicieli tego zawodu oznak prestiżu (poza satysfakcją zawodową) zapewne pozwoli nauczycielom zwiększyć motywację do podejmowania dalszych działań, co w efekcie będzie sprzyjało podniesieniu jakości kształcenia w polskich szkołach.

\section{Bibliografia}

Dobrodziej P., Słownik badań marketingowych, rynkowych i społecznych, http://dobre badania.pl/słownik-badawczy.html (dostęp: 2.05.2013).

Domański H., Co wynika z badań dla prestiżu nauczyciela w Polsce?, referat wygłoszony w czasie Kongresu Polskiej Edukacji w Warszawie w dniu 16.06.2013 r.

Domański H., Prestiż, Wrocław 1999.

Falkowska M., Prestiż zawodów, Komunikat CBOS nr 1355, Warszawa 1995 (data wydania: 9.03.1995)

Falkowska M., Prestiż zawodów, Komunikat CBOS nr 2086, Warszawa 1999 (data wydania: 3.03.1999).

Feliksiak M., Prestiż zawodów, Komunikat CBOS nr 4073, Warszawa 2009 (data wydania: 20.01.2009).

Feliksiak M., Wizerunek nauczycieli, Komunikat CBOS nr 4753, Warszawa 2012 (data wydania: 19.12.2012).

Goetz M., Gdzie ten prestiż?, http://www.eurydice.org.pl/sites/eurydice.org.pl/files/gtp.pdf (dostęp: 1.12.2013).

Goetz M., Roszczeniowe samoluby, „Przekrój”, 24.06.2012.

Jabłońska G., W pogoni za prestiżem, czyli najbardziej poważane zawody w Polsce, http:// www.rynekpracy.pl/artykul.php/wpis.107 (dostęp: 7.04.2009).

Jaki jest najtatwiejszy zawód świata?, http://pytamy.pl/kat,17,title,jaki-jest-najlatwiejszyzawod-swiata,pytanie.html (dostęp: 19.10.2009).

Janowski A., Stachyra R., Prestiż ucznia wśród rówieśników, Warszawa 1985.

Kopaliński W., Stownik wyrazów obcych i zwrotów obcojęzycznych $z$ almanachem, Warszawa 2000.

Majewska-Opiełka I., Obyś cudze dzieci uczył!, „Edukacja i Dialog” 2008, nr 3.

Marshall G. (red.), Stownik socjologii i nauk społecznych, Warszawa 2006.

Mocek S., Prestiż zawodów, Komunikat CBOS nr 0978, Warszawa 1993 (data wydania: 10.03.1993).

\footnotetext{
${ }^{34}$ H. Domański, Co wynika z badań dla prestiżu...
} 
Najbardziej hańbiący zawód dla k/m to?, http://pytamy.pl/kat,6,title,najbardziej-hanbiacyzawod-dla-k-m-to,pytanie.html (dostęp: 14.04.2009).

Najbardziej romantyczny zawód na świecie?, http://pytamy.pl/kat,12,title,najbardziejromantyczny-zawod-na-swiecie,pytanie.html (dostęp: 19.05.2008).

Polacy o zawodach, Komunikat OBOP, Warszawa 2000.

Praca (II) - Czynnik stratyfikacji społecznej, http://socjoszpieg.blox.pl/2007/01/Praca-II-Czynnik-stratyfikacji-spolecznej.html (data publikacji: 12.01.2007).

Rogulska B., Prestiż zawodów a struktura zarobków, Komunikat CBOS nr 1635, Warszawa 1996 (dostęp: 1.09.1996).

Sowiński C., Jakie zawody sa przez ludzi cenione, Komunikat CBOS nr 0321, Warszawa 1988 (dostęp: 15.02.1988).

Szewczenko A., Jacek Santorski: Dla jednych prestiż to dtugo działajacca firma. Dla drugich - Rolex, http://www.podlaskie.strefabiznesu.pl/artykul/jacek-santorski-dla-jednychprestiz-dlugo-dzialajaca-firma-dla-drugich-rolex-32815.html (dostęp: 25.03.2010).

Sztompka P., Socjologia. Analiza społeczeństwa, Kraków 2010. 